\title{
O REGENTE SEM ORQUESTRA: NOTAS DE UMA ETNOGRAFIA DA AUDIÇÃO
}

\section{THE CONDUCTOR WITHOUT AN ORCHESTRA: NOTES OF AN ETHNOGRAPHY OF HEARING}

\section{Tamara de Souza Campos}

tamara.campos86@gmail.com

Doutora em Memória Social (UNIRIO),

Professora de Comunicação Social da UNESA

ORCID: https://orcid.org/0000-0001-7662-1143

\section{RESUMO}

O artigo apresenta uma prática de etnografia da audição ou sonora, que pode embasar trabalhos que investiguem mundos sonoros propondo uma conjugação do ver e ouvir, em vez de uma hierarquia entre ambos, do que resultaria pensar em termos de paisagens sonoras ou dos sons enquanto imagens simbólicas. O campo teve duração de quase dois anos e foi realizado em uma escola de Música, onde acompanhei o processo de formação profissional de um maestro de orquestra. No auge de uma sociedade imagética, o campo é um reduto de pessoas que primam por uma relação diferenciada com a vida e no contato com seus pares. Reflito sobre as faculdades do ver e do ouvir, intensamente discutidas pela Antropologia, e comparo às peculiaridades observadas in loco. A conclusão é de que audição e visão estão imbricadas o tempo todo no campo, compondo imagens sonoras que são interpretadas pelos nativos e mobilizadas na performance, auxiliando de modo mais efetivo tanto o convívio entre os músicos quanto a execução musical.

Palavras-chave: etnografia; audição; visão; música.

\section{ABSTRACT}

The article presents a practice of hearing or sound ethnography, which can support works that investigate sound worlds proposing a combination of seeing and hearing, instead of a hierarchy between both, of what would result thinking in terms of soundscapes or sounds as images symbolic. The field lasted for almost two years and was held in a music school, where I followed the professional training process of an orchestra conductor. At the height of an imaginary society, the countryside is a stronghold of people who excel in a differentiated relationship with life and in contact with their peers. I reflect on the faculties of seeing and hearing, intensively discussed by Anthropology and comparing them to the peculiarities observed in loco. The conclusion is that hearing and vision are interwoven all the time in the field, composing sound images that are interpreted by the natives and mobilized in the performance, helping in a more effective way both the interaction between the musicians and the musical performance.

Keywords: ethnography; hearing; vision; music. 


\section{INTRODUÇÃO: UM POUCO SOBRE O CAMPO}

O objetivo do presente artigo é analisar as categorias "ouvir" e "ver" no campo da Antropologia, especialmente, em conformidade com a natureza do campo de pesquisa - no caso, uma escola de Música de uma universidade federal no Rio de Janeiro. Vale lembrar que a música tem natureza ambivalente, ao mesmo tempo sendo universal, posto que está presente em todas as sociedades, mas deve ser vista a partir de um prisma contextual, pois é "singular e de difícil tradução, quando apresentada fora de seu contexto ou de seu meio cultural" (PINTO, 2001, p. 223).

A peculiaridade da escola de Música residia no fato de os nativos viverem em um universo no qual se dedicavam a um "objeto diferenciado entre os objetos concretos que povoam o nosso imaginário", [...] pois, por mais que percebamos o som, ele é "invisível e impalpável. O senso comum identifica a materialidade dos corpos físicos pela visão e pelo tato. Estamos acostumados a basear a realidade nesses sentidos" (WISNIK, 2011, p. 28). Isso torna investigações cujo enfoque residem nos sentidos culturais do som bastante desafiadoras, pois está em jogo os sons ou acústica, além dos sons organizados culturalmente ou sonoridades (BASTOS, 1995). Essa prevalência da visão também marcou vários estudos da Antropologia (STOLLER, 1989; SEEGER, 1979; GELL, 1995), como veremos adiante, mas são relativizados neste trabalho à luz do observado em campo, em consonância com Ingold (2008), que defende uma indissociabilidade entre os sentidos, compreendendo que as percepções visuais e auditivas estão em simbiose, seja com um "olho que ouve" ou um "ouvido que vê" (INGOLD, 2008, p. 26).

O objetivo geral da pesquisa, a partir da qual esse artigo se erige, era investigar o processo de formação de um regente de orquestra e compreender a construção do ethos desse profissional por meio de uma visão êmica dos atores implicados nessa formação (estudante/músico e maestro/professor). O corpus, portanto, advém das observações em campo, tendo sido registrado em arquivos de áudio gravados no celular, além das anotações no diário de campo.

O campo foi desenvolvido de setembro de 2013 a abril de 2015, como parte da pesquisa de doutoramento da autora. De forma a preservar as identidades dos colaboradores de pesquisa, em atendimento a Resolução CNS 196/96, sempre que me referir ao maestro será pelo pseudônimo Samuel. Nomeio o aluno de regência de Rodrigo.

Como não podia acompanhar toda a rotina do aluno em formação, optei por assistir às aulas de Prática de Orquestra, na qual Samuel regia a orquestra composta por todos os alunos de bacharelados em instrumentos musicais da universidade. Rodrigo era um espectador desses ensaios, nos quais tinha oportunidade de conversar com ele. As práticas de orquestra de alunos, sempre conduzidas por Samuel, funcionavam como laboratório para Rodrigo, pois, o maestro, geralmente exigia do discente a regência das mesmas peças nas aulas de Regência I, II e III, 
que ocorriam logo após os ensaios, e que também observei. As aulas de regência eram integradas apenas pelo professor, Rodrigo e eu, sendo o principal objetivo o estudo corporal das técnicas de regência, a partir da leitura de partituras previamente estudadas pelo aluno. Samuel, durante as aulas, dava um feedback constante da performance do discente. Durante essas aulas de regência, algumas situações ocorridas no ensaio da orquestra de alunos eram tematizadas por discente, docente e pela pesquisadora, o que tornou o campo frutífero e pôde contribuir na reflexão sobre os atos de ver e ouvir, com especificidades que os diferenciam do tradicionalmente enfatizado por teorias antropológicas.

\section{SOBRE O VER E O OUVIR ETNOGRÁFICOS}

Um pressuposto básico da pesquisa etnográfica é o de que o pesquisador deve ocupar uma posição no campo que estuda, que o mesmo precisa situar-se. $\mathrm{O}$ aspirante a antropólogo aprende desde cedo que o uso dos cinco sentidos durante a investigação é fundamental. Visão, olfato, paladar, tato, audição são ativados e convocados ao longo do trabalho, e o etnógrafo deve ter a sensibilidade para perceber esse chamado dos sentidos e exercê-los para compreender a realidade estudada, pois "observação é o ato de perceber as atividades e os inter-relacionamentos das pessoas no cenário de campo através dos cinco sentidos do pesquisador", embora saibamos que "a objetividade de nossos cinco sentidos não é absoluta” (ANGROSINO, 2009, p. 56).

A subjetividade está sempre presente no trabalho de campo, por mais que o pesquisador se esforce para apresentar uma realidade "objetiva"; portanto, a "interpretação está sendo constantemente testada, revista e confrontada, especialmente em pesquisas urbanas, que se diferenciam de estudos em comunidades distantes ou exóticas, pois, as últimas, dificilmente permitem diferentes pontos de vista (VELHO, 1978). As considerações que pesquisadores das humanidades estabelecem, especialmente em etnografia urbana, são uma versão dos fatos, uma interpretação, uma memória acerca do objeto que o pesquisador ajuda a construir. O trabalho de Silva (2005), por exemplo, também oferece uma determinada mirada acerca dos estudantes de música da mesma universidade na qual se desenrolara meu campo.

Como o exercício é entender o mundo do outro e os sujeitos que povoam o lócus pesquisado, o etnógrafo deve recorrer a todos esses sentidos - ums mais, outros menos, dependendo do caráter do local. É uma tentativa de entender a vida do outro que, para viver, utiliza obviamente os cinco sentidos, razão pela qual o antropólogo busca operar com todas as ferramentas sensoriais possíveis. Vale aqui marcar uma distinção, pois uma coisa é entender a visão e a audição como faculdades do indivíduo, outra é pensar o ver e o ouvir como ferramentas usadas pelo pesquisador, o que exigiria uma sensibilização e treinamento 
dessas capacidades. Isso acaba se tornando um desafio na medida em que "raras são as pesquisas que experimentam e expressam informações antropológicas a partir de sons, temperaturas, cheios, gostos, emoções e incorporações (GAMA, 2016, p. 118). Sons e música mobilizam muito a questão dos afetos e da emoção, sugerindo uma subjetividade ainda mais potente.

Há, ainda, o entendimento do ver e do ouvir enquanto etapas do método do etnógrafo. Roberto Cardoso de Oliveira pensa o "ver, o ouvir e o escrever" como constituintes da pesquisa antropológica, pois "estão previamente comprometidos com o próprio horizonte da disciplina, [...] estão desde sempre sintonizados com o sistema de ideias e valores que são próprios da disciplina" (OLIVEIRA, 2000, p. 32). Ele pensa o método etnográfico, a partir de Geertz, em duas etapas distintas: o "estando lá" (no sítio da pesquisa) e o "estando aqui” (OLIVEIRA, 2000, p. 25) (no local de origem do antropólogo, retomando a vida normal e contato com pares). Na etapa do "estando lá", incluindo a preparação, o ver e o ouvir estão fortemente presentes. Importante ressaltar que ouvir e ver estão constantemente imbricados, tanto quando o pesquisador lê e levanta documentos, vídeos e monografias que forneçam elementos para aprimorar os conhecimentos sobre o campo que será pesquisado, bem como quando o exercício da observação participante, respaldado pela preparação para o campo, que ajudou a "conformar" um determinado olhar, e da conjugação com teorias que ajudem a ancorar esse olhar, possibilitando um maior grau de objetividade para os fenômenos observados.

A mesma lógica se aplica ao ouvir, faculdade bastante estimulada durante meu trabalho de campo, devido à natureza do local, mas trabalhada por mim também na fase de preparação para imersão. Posso citar tanto a escuta de mais obras sinfônicas e vídeos que ensinavam a reger na internet quanto a entrevista piloto, realizada com um maestro, com duração aproximada de sessenta minutos, na qual eu procurei compreender melhor a área da regência, para sanar algumas dúvidas antes do ingressar no campo. Nesses exemplos, ocorre a conjugação do binômio visão-audição.

Todos, normalmente, acionamos os cinco sentidos, mas o etnógrafo precisa discipliná-los, pois, por mais que não queiramos olhar com lentes etnocêntricas, ao termos contato com o objeto lembramos de autores que já lemos e que exploraram e descreveram a temática, e de várias outras referências que ajudam a orientar o nosso olhar, ou seja, é um olhar que deve ser "devidamente sensibilizado pela teoria disponível (OLIVEIRA, 2000, p. 19). Isso não é propriamente ruim e, na verdade, é necessário, caso contrário não teríamos condições de perceber e refletir mais profundamente, apenas olharíamos por olhar. É notória a distinção entre olhar e ver, pois, "ver, sendo diferente de olhar pura e simplesmente, implica uma organização do que foi olhado, espiado, es- 
pionado, entrevisto, reparado, notado, percebido ao longo do percurso etnográfico" (SILVA, 2009, p. 181). Em termos práticos, fazer pesquisa com informações prévias sobre o objeto ajuda nessa organização do olhar, como relata Roberto Cardoso de Oliveira, ao propor que imaginemos que um jovem antropólogo comece uma pesquisa com os índios Tükúna, no Alto do Rio Solimões, no Amazonas, tendo o pesquisador lido relatos antigos sobre esse grupamento. O antropólogo não olharia para o objeto de maneira ingênua, e se daria conta de que as malocas observadas por ele "diferenciavam-se radicalmente daquelas descritas pelos cronistas ou viajantes [...]” (OLIVEIRA, 2000, p. 20).

Na observação participante, de modo geral, é possível notar uma certa prevalência da visão, o que pode ser parcialmente explicado pelo fato de a antropologia física e a filosofia, desde pelo menos o século XIX, primarem pela visão, sentido esse geralmente valorizado em atividades intelectuais (LE BRETON, 2016). A expressão "olhar etnográfico", de certa forma, já sinaliza essa predileção, bem como "observação participante", já que observação, apesar de não excluir os outros sentidos, imediatamente remete à questão do olhar. Outro exemplo é a construção "livros de andar e ver" (SILVA, 2009). O teórico entende a atividade do antropólogo como um percurso, como um profissional que faz "um registro de andanças e coisas vistas" (SILVA, 2009, p. 175).

Há uma preferência pela visão nos métodos antropológicos, até porque a disciplina foi validada enquanto ciência que olha e retrata o outro. Mas Ingold (2008) analisa que o modo como alguns teóricos interpretaram a cultura do outro pode ter sido influenciado pela nossa própria cultura ocidental. Ocorre que Paul Stoller (1989), ao analisar os Songhay do Níger, na África Ocidental, conclui que o som seria o sentido mais fundamental na experiência desses nativos, nas cerimônias de possessão e poesias de louvor, os espíritos adentrariam os indivíduos por meio do som, que invade, ao passo que o olhar distancia. A conclusão de Stoller (1989) é que o som cria pontes, vem do exterior ao encontro dos nativos, enquanto a visão estabeleceria uma divisão entre observador e objeto observado.

Conclusão parecida é tomada por Seeger (1979), ao dizer que a audição e a fala são supervalorizados, seja através dos lóbulos da orelha estendidos dos suyá, ou inserção de discos de madeiras nos lábios inferiores. A própria palavra kum-ba, na língua local, significa conhecer, entender, bem ouvir. Ou seja, conhecer é um fenômeno que ocorreria por meio da audição. Seerger (1987) avança e diz que o sentido aguçado da audição é encarado como uma virtude entre os sunyá, em contrapartida ao da visão, que seria indesejado, tido como bruxaria e com conotações de desvio, no sentido da delinquência.

Por fim, os Umeda, povo nativo de Papua Nova Guiné, ao habitarem uma densa floresta precisam reorganizar suas sensibilidades, pois a visão não seria o melhor guia. Gell (1995) conclui que tais indivíduos, 
então, primam pela audição e olfato, em detrimento da visão. Há uma imersão em um ambiente sonoro, o que, para Geel (1995) resultaria, inclusive, em uma maior solidariedade, em comparação com as culturas ditas visuais.

Ingold (2008) analisa esses três estudos e descontrói essa primaria aural, percebendo que a visão também seria importante e utilizada pelos povos, em diálogo com a própria audição. Ele chama a atenção para o contraste entre audição e visão, nos três trabalhos, que estariam alinhados com uma visão tradicional no Ocidente de que enquanto o som penetra, a visão isola. $\mathrm{O}$ som seria dinâmico, ao passo que a visão seria estática, o som seria coletivo e a visão um ato individual. De um modo mais geral, ouvir seria participar, e ver seria observar à distância.

Uma das ironias da crítica contemporânea do visualismo é que ao clamar pela restauração da audição a seu devido lugar na proporção dos sentidos, ela, na verdade, reproduz essa oposição entre a audição e a visão e, com ela, um conceito de visão muito limitado e empobrecido para o qual seu alistamento no projeto da modernidade nos trouxe (INGOLD, 2008, p. 12).

Os trabalhos de Verdana (2010) e Gama (2016) também transcendem essa dicotomia visão/audição, percebendo um panorama mais holístico e com menos binarismos. Teóricos que se dedicam à Antropologia da Música reconhecem, no entanto, que essa valorização do olhar ainda é muito presente, como é o caso de Pinto (2001):

A sensação de ouvir foi, durante séculos, dominada pela percepção visual. Mesmo que pesquisas científicas mais recentes tenham recuperado este sentido enquanto seus aspectos físico, cultural e mesmo social, discursos analíticos no campo da antropologia permanecem centrados no imagético e são poucos aqueles que contrapõem a discussão sobre o som à predominância da visualidade nas ciências humanas e sociais ( $\mathrm{p}$. 222).

O etnomusicólogo analisa como "a música espelha a cultura ou logo criticada esta formulação - como a música produz e reproduz valores, identidades e grupos sociais" (TRAVASSOS, 2003, p. 78). Mas não podemos cair na armadilha de partimos do pressuposto do olho como o órgão responsável pela razão, compreendendo, melancolicamente, a capacidade audível como algo que fora perdido pelo Ocidente.

Importante marcar que as investigações de universos musicais evoluíram muito desde o início do século XX. Se, em um primeiro momento, a chamada Musicologia lidava com as estruturas dos sons, apartando a dimensão antropológica, avança-se para o entendimento do estudo da música enquanto cultura, das pessoas "fazendo música", independentemente de "origem de lugar geográfico e da relação do produto sonoro com a cultura do pesquisador" (PINTO, 2011, p. 226).

Durante muitos séculos a realidade social dos grupamentos orais privilegiou a audição, mas, pouco a pouco, especialmente a partir da 
tipografia e da prensa, o ocidente dotou "a visão de uma superioridade que vai se impondo no mundo contemporâneo (LE BRETON, 2016, p. 39). Para além do livro e da prensa, a supervalorização da visão tem relação com um processo de urbanização e uma cultura de mídia de massa, que promovem uma superexposição às imagens.

Por isso, o pesquisador que lide com etnografia deve fazer um esforço para acionar e interpretar o mundo do outro a partir dos cinco sentidos, estando atento para os regimes de sensorialidade que vigoram, a dinâmica da partilha do sensível:

A matéria do escrever, isto é, o que a escrita modela, é a matéria da visão, da audição, do olfato, do tato, do paladar, mas sobretudo as sensações compósitas, as percepções produzidas por múltiplos canais, pelos cruzamentos áudio-táteis, palato-visuais, as sensações produzidas pela mistura "daquela música" com àquele cheiro (SILVA, 2009, p. 183).

Silva ressalta não só a importância dos sentidos no trabalho antropológico, mas na articulação entre os mesmos, já que não vivenciamos um momento nos despindo de algum de nossos sentidos. Oliveira também reconhece os sentidos presentes no ato da escrita, embora o foco de sua análise gire em torno da visão e da audição, justamente por ele perceber que elas são constituintes do "estar lá". Para ele, "o escrever etnografia é uma continuação do confronto intercultural [...] uma continuidade do olhar e do ouvir no escrever [...]" (OLIVEIRA, 2000, p. 33).

Importante marcar também que apresentei, até o momento, uma perspectiva mais consolidada do "ver" e "ouvir" na antropologia. A perspectiva de Verdana (2010), sobre as "etnografias sonoras", percebe o ver e o ouvir como imbricados, indissociáveis. A premissa levada a cabo por Verdana (2010) e os demais membros do Núcleo de Pesquisas sobre Culturas Contemporâneas, do Programa de Pós-Graduação em Antropologia Social da UFRGS, a partir do Banco de Imagens e Efeitos Visuais (BIEV), é compreender como etnografias sonoras trabalhos nos quais sonoridades, ritmos e ruídos ajudem a formar ambiências e paisagens sonoras. Mas, ao considerarem o som uma "imagem simbólica", influenciados por Durand (2001), visão e audição se associam, configurando um objeto imagético-sonoro.

Para Maffesoli (1996, p. 112), pensar o território sonoro é se valer de imagens sonoras que percebemos e escutamos, os gestos, práticas e simbolismos inerentes. É nesse sentido que a postura de investigação se volta para uma imaginação criadora, o que romperia a suposta objetividade científica. Ingold (2008) pensa parecido, ao postular, a partir de Merleau-Ponty (1964), que não há um espectador imóvel que contempla sem engajamento, mas um sujeito vidente que ao olhar se aproxima. Nesse sentido, há um espaço visual habitado por nós, o que ajudaria a dissolver a fronteira exterior/interior. 


\section{ESCUTA ATIVA MUSICAL E IMAGINAÇÃO MUSICAL}

Minhas experiências na escola de música costumavam instigar intensamente o ouvido e a visão, pois a escola de música envolvia distintas ambiências sonoras e performances, que envolvem um forte componente visual. Nessa perspectiva de sons como imagens simbólicas e de performance, todos os sentidos eram convocados, pois o que ocorria no campo era uma performance, ou seja, comportamento e modos de viver experiências em consonância com a noção de performance de Turner (1985), que não restringe a mesma a rituais, cerimônias ou apresentações, mas também a muitos domínios da vida ordinária, seja na realidade tribal ou urbana atual. Assim, todos os cinco sentidos estavam presentes - estes apenas não dialogaram tanto com a natureza do campo, pois não eram tão manifestos quanto o ouvir e o ver.

Com relação ao olfato, é possível citar um cheiro de mofo que em algumas ocasiões exalava da sala-auditório, excepcionalmente forte quando o ar-condicionado não funcionava a contento, o que ocorreu algumas vezes, ou o cheiro do cachorro quente que ficava em uma das entradas da universidade e que era lanche usual meu e do aluno de regência. Aliás, normalmente não seria minha escolha de lanche, mas era uma oportunidade para conversar mais com Rodrigo, sem ficar constrangida em fazer barulho durante a prática de orquestra.

A dimensão tátil esteve presente quando segurei, pela primeira vez, a batuta e instrumentos, como fagote, clarineta e violino; quando brinquei de reger durante as aulas e, presente também em alguns gestos, como quando fechava o punho e fazia "o corte" junto com Rodrigo ou Samuel, e sentia o contato dos dedos na palma das mãos e um certo poder que o gesto inspira, pois é um sinal de comando para que os músicos parem de tocar. Tal dimensão tátil era importante na vida dos nativos, especialmente o regente.

Muitas situações no campo demonstram a importância da capacidade auditiva/visual para os nativos, tanto para Samuel, quanto para Rodrigo e os alunos da orquestra. Normalmente, fora as áreas de convivência, como cantinas e pátio, a universidade costuma ser marcada pelo silêncio, especialmente se adentrarmos os prédios no momento das aulas. A realidade da faculdade de música era bem diversa, com diferentes sonoridades povoando, as imediações do prédio, o pátio, os corredores e as salas de aula. Escutava distintas melodias, muitas vezes se sobrepondo umas às outras, o tempo todo. Alguns alunos tocavam para serem vistos, o que nos remete ao som como imagem simbólica e à performance, como era o caso de um violinista que parceria sempre se posicionar em alguma passagem estratégica, fazendo até parcerias performáticas com alguns alunos de teatro. Em certa ocasião, bem no meio do pátio principal, alguns alunos de teatro iam se retorcendo e se expressando a partir da música vinda do violino. As conversas eram embaladas por esse som que emanava de um músico ensaiando de um canto ou de uma 
sala de aula. Os músicos, ao conversarem, muitas vezes cantarolavam trechos, já que boa parte das conversas girava em torno da música, de instrumentos, obras, músicos famosos, apresentações e, obviamente, da rotina na universidade.

Esse cantarolar era uma ferramenta legítima não só em conversas informais, mas dentro de sala de aula, no contato entre docente e alunos da orquestra e na aula de regência. Em vez de se valer de uma explicação verbal, ou verbal associada à escrita no quadro negro, típica de uma sala de aula, o maestro recorria ao solfejo como estratégia elucidativa. Tais práticas de alunos e do maestro nos remetem novamente à questão da performance, devido ao drama social envolvido. Os nativos, nesse sentido, não fazem apenas as coisas, mas tentam 'mostrar' o que fazem. As ações são performatizadas para os pares, numa relação de reciprocidade, deixando claro o domínio de um saber-fazer e saber-ser que são valorizados pelo grupo em questão (TURNER, 1988).

Associado ao solfejo, em algumas ocasiões, ele também estalava os dedos para marcar o tempo. É como se as estaladas funcionassem como um metrônomo, enfatizando a questão rítmica, e o solfejo correspondesse à parte harmônica, ressaltando a melodia. Músicos, a fim de tirarem dúvidas, também cantarolam para o maestro checar se está correto, o que deixa claro o aprendizado corpóreo envolvido na performatização. No entanto, nunca vivenciei uma situação em que os músicos solfejassem e estalassem os dedos ao mesmo tempo. Um dia, no campo, por meio de uma explicação do maestro, consegui compreender esse fato, pois o regente afirmou que "músico não estuda com metrônomo". Lembrou, inclusive, de sua experiência durante o Mestrado na Alemanha, em que seus colegas o chamavam de "o latino", por estudar sem o metrônomo, já que na Europa e nos EUA os músicos de orquestra costumam adotar o aparelho na rotina de estudo individual. Teria sido a partir desse momento que o maestro, na época um flautista, começara a usar o equipamento em seus estudos. O próprio aluno de regência, quando era apenas trombonista, confessou que não usava metrônomo e que havia começado a adotá-lo após as recomendações do maestro na aula de regência, alegando estar "muito mais preocupado agora com a questão rítmica" (Rodrigo. Notas de campo. Abril de 2014).

O problema da questão rítmica não estava relacionado apenas ao fato dos músicos não utilizarem o metrônomo, mas também em decorrência de não se escutarem e não ouvirem uns aos outros, queixa constante de Samuel:

A leitura que os músicos da orquestra de alunos fazem é errada, mesmo eles tendo experiência. Eles não entendem a importância de se ouvir e de enxergar o maestro. Não existe música fácil. A chave é o tempo, mas eles não se ouvem. Porque eles ficam grudados na parte dele e o que o outro está tocando ele não liga. Eles precisam aprender a ouvir. O cara chega com a parte dele, não abre o ouvido. Aí não vai ficar 100\% integrado, né? (Nota de campo. Abril de 2014). 
Para o músico garantir uma execução correta, não basta que ele apenas domine a sua parte e/ou se valha de uma boa leitura da partitura (visão), que funciona como um suporte de memória. Fazer parte de uma orquestra envolve um trabalho interacional intenso, uma performatização que é individual e coletiva, acionando o tato, a visão e a audição. Pressupõe o monitoramento do contexto, de si e dos outros, incluindo o maestro e os demais colegas instrumentistas, a fim de ficar $100 \%$ integrado, como sugere a fala de Samuel. Ou seja, a performance de um músico e maestro no campo pesquisado envolve um saber ler e se posicionar num plano sensório complexo. $\mathrm{O}$ monitoramento do outro pode ser exemplificado pelo fato de que muitas vezes a voz de um instrumento é a deixa para que o outro assuma o turno de fala ou quando o músico precisa tocar em uníssono com o colega de instrumento. Enfim, são muitas as situações que envolvem diferentes posicionamentos, ou "alinhamentos" (GOFFMAN, 2002), categorias estas da Sociolinguística Interacional.

Há, portanto, um esquema de expectativas e obrigações que incidem sobres os músicos do universo orquestral, tais como: "estou soando conforme meus colegas de naipe?"; "toco no tempo indicado na partitura?"; "estou atendendo às indicações do maestro?"; "as notas estão soando bonitas?"; "atendo àquilo que o compositor idealizou ao criar a peça musical?"; "meu corpo expressa o sentimento que busco passar?". No momento da apresentação não há espaço para o discurso verbal, pois, obviamente, este rivalizaria com a própria música, objetivo fim de um ensaio ou apresentação. As preocupações dos músicos evocam uma certa paisagem sonora típica do meio orquestral.

Devido a esse uso muito restrito do registro verbal, já que oralidade rivalizaria com o som dos instrumentos, na orquestra é valorizada também a linguagem corporal, sendo "o ideal é passar tudo pelo corpo e não falar muito. A batuta é aliada nesse processo" (Samuel. Notas de campo, julho de 2015).

O conceito de "recepção tátil" de Benjamim (1993, p. 192-194) pode nos auxiliar a compreender essa dimensão tátil da regência e da Música. Benjamin diferencia dois tipos de recepção, a tátil, que se daria pelo hábito, pelo uso, e a recepção ótica, relacionada à atencão, à percepção. $\mathrm{O}$ autor utiliza a arquitetura como exemplo para pensar nessa dupla forma de percepção, pois além de percebermos o prédio em seus aspectos estéticos também o usamos, o habitamos. O autor diz, ainda, que a recepção ótica pode ser uma etapa da recepção tátil, já que a nossa resposta, nosso uso e ação estão relacionados à nossa capacidade de perceber, pois "as tarefas impostas ao aparelho perceptivo do homem [...] são insolúveis na perspectiva puramente ótica: pela contemplação. Elas se tornam realizáveis, gradualmente, pela recepção tátil, através do hábito" (BENJAMIN, 1993, p. 193). A música teria um forte componente tátil, por envolver o ouvinte ou o músico enquanto ouvinte de sua própria 
performance. Sob o ponto de vista do músico, ela seria tátil por exigir o próprio corpo do artista em sua totalidade, tanto para execução como expressão. O mesmo vale para o maestro, que precisa escutar todos os instrumentos e, ao mesmo tempo, dar comandos para fazer a música acontecer. Interessante perceber ainda o diálogo entre a noção de som como imagem simbólica (DURAND, 2001), de um território sonoro repleto de imagens sonoras (MAFFESOLI, 1996), ou como Ingold (2008), que entende o ver totalmente conjugado ao ouvir, como um espaço sensório que deve ser habitado.

A música é uma linguagem, que envolve códigos específicos e uma gramática própria, dominada por músicos profissionais e maestros de orquestra. Tal linguagem é lida, interpretada, convertida em som e subentende não apenas os símbolos/sons grafados na partitura, mas toda uma dinâmica corpórea-gestual e de respiração, inclusive. Há um trabalho interacional intenso, tanto nos ensaios quanto no hic et nunc dos espetáculos, nos quais os atores se reposicionam de modo constante, a partir de um trabalho de monitoramento intenso do contexto e uma performance que leva em conta o que ouvem e observam de seus colegas, interpretando e re-interpretando a partitura e percebendo a intenção do maestro - tudo isso em tempo real, no momento que o músico executa a obra. Fica claro então que as práticas musicais devem ser compreendidas "a partir de perspectivas contextuais, como evento e como processo, englobando dimensões sonoras, comportamentais, simbólicas e interativas" (RIBEIRO, 2017, p. 336). Por tais razões, por meio da performance podemos compreender a comunidade cultural dos músicos, a partir de suas formas de viver e expressar experiências.

Os próprios instrumentos representam vozes, que devem ser emitidos nos momentos apropriados (de acordo com o que está escrito na partitura e no tempo da música) e da maneira apropriada (conforme os comandos do maestro, com o colorido que a obra exige, respeitando as dinâmicas). O músico se alinha tomando por base o contexto que a obra fornece (os conhecimentos sobre o autor da peça, contexto sócio histórico em que a mesma foi produzida, intenção do autor, movimento artístico ao qual pertencia), a partir de como percebe que seus colegas de orquestra e de naipe estão executando e interpretando a obra e baseado nas indicações do maestro. Todos esses elementos fornecem, para o ensaio e/ou apresentação, um enquadre e tal monitoramento é da ordem tátil (habilidade ao segurar e tocar o instrumento no músico e com a batuta, para o maestro), visual (olhar para os músicos, no caso do maestro e olhar para o maestro e mesmo a expressão fácil dos colegas, pois isso também ajuda a passar o caráter da obra), além da própria questão auditiva (escutar o que você e os colegas tocam). Novamente fica nítida aqui a questão do som como uma imagem simbólica (DURAND, 2001) ou, nos termos de Ingold (2008) a dissociabilidade entre som e visão. 
Caso perceba que sua projeção não é das melhores, o músico tem a oportunidade de se realinhar, ou seja, alterar sua performance, seja mudando a maneira como toca, o "andamento", sua expressão facial e corporal, sua intenção. Cabe explicar brevemente a ideia de andamento, que representa um jargão. $\mathrm{O}$ andamento implica manter a orquestra tocando no tempo. Já o piano seria uma das categorias do que chamamos de dinâmica musical, que está relacionada com o modo de tocar, com a intensidade, a energia dispendida. Vai do quase inaudível (pianissíssimo, representado na partitura como "ppp") ao máximo de som que poderia se obter de um instrumento, sem danificá-lo (o fortissíssimo, representado por "fff”). Há ainda, em ordem crescente, o pianíssimo $(\mathrm{pp})$, piano (p), mezzo-piano (mp), mezzo-forte (mf), forte (f) e fortíssimo (ff), além dos dois extremos citados anteriormente.

O maestro, ao dar as entradas, convoca as vozes musicais a falar, "desfruta, assim, do poder sobre a vida e a morte dessas vozes" (CANETTI, 1995, p. 395). Na condição de líder, a falha muitas vezes acaba ficando associada ao regente, que não teria conduzido a contento, pois, como o aluno de regência disse em uma aula, “a orquestra é o reflexo do maestro".

As entradas são fundamentais para que instrumentistas não entrem adiantados ou atrasados, atrapalhando o bom andamento da obra. E a dinâmica musical significa tocar conforme sinalizado na partitura, ou ainda, de acordo com o que o maestro solicitou, já que não é incomum que os maestros alterem algumas dinâmicas se julgarem necessário para uma melhor apresentação.

A interpretação dos alinhamentos no ensaio, portanto, é tarefa altamente complexa, pois é uma atividade muito dinâmica, exigindo que músicos e maestros alterem suas posições constantemente, sendo o maestro talvez o único capaz de entender cada mudança de posição. Isso resulta em uma performance na qual razão e afeto estão presentes, tanto nos ensaios da orquestra quanto na apresentação. Os conhecimentos musicais são tão valorizados que integram o cotidiano performáticos desses nativos, o que é perceptível, em conversas cantaroladas, conforme já explorado.

Como analista, não possuo o conhecimento musical exigido para entender todas essas sutilezas de (re)posicionamento dos instrumentistas e do maestro, que ocorrem a partir da execução musical que projetam. A orquestra envolve muitos componentes, como diferentes famílias de instrumento, que executam diferentes peças ao longo da apresentação, cada qual com um caráter próprio, sendo que muitas músicas apresentam mudança de caráter ao longo, começando mais romântica, por exemplo, sendo seguida por um motivo dramático e retornando ao tema romântico no encerramento - tudo isso apenas para sinalizar o alto grau de complexidade na encenação dramática de uma apresentação musical. 
Em um dia de ensaio da orquestra de alunos, os gestos, as expressões faciais e a dinâmica corporal de Samuel não foram suficientes para os músicos compreenderem como deveriam executar um trecho de Pavane, de Gabriel Fauré, um compositor francês nascido em 1845. Samuel explicou então que "o segundo violino e a flautista precisam tocar claro, articulado. Precisam brilhar! Vocês são os pássaros, os primeiros violinos representam uma nuvem. O cenário é o paraíso" (Notas de campo. Setembro de 2014). Para o maestro, os instrumentistas não estavam respeitando a natureza da composição, apesar da execução correta das notas e de estarem no tempo certo. Faltava irem ao encontro do que Samuel interpretou ser a vontade do compositor que, no caso, era retratar sonoramente o paraíso, novamente nos remetendo ao som como imagem simbólica (DURAND, 2001). Mas, ao término do ensaio, após o maestro ter se retirado, um músico comenta com o colega: "você percebeu essa coisa do paraíso da regência dele? Porque eu não", ao que o outro músico ri com certo escárnio. Isso demonstra um sistema de valores no qual a comunicação não verbal deve ser objetiva na performance desses atores, apesar da música, paradoxalmente, ser também emoção.

O monitoramento que o músico faz dos outros instrumentistas é auditivo e visual, especialmente na interação com o maestro, muito pautada no gestual e olhar que devem ser decodificados pelos instrumentistas. Essa representação dramática exige que o músico escute suas notas, analise como está soando, e, muitas vezes, ajuste a emissão no decorrer de um trecho, em tempo real, de acordo com o que julga melhor. Ouvir, para os nativos, é pura ação; é performance, envolvendo tanto as recepções tátil quanto ótica (BENJAMIN, 1993), funcionando esta como uma condição para a realização daquela.

O grau de complexidade das obras musicais faz com que o músico seja um perito do ouvido. Tal escuta é característica dos músicos profissionais, sendo que, "o lugar dessa lógica é a técnica; para aquele que também pensa com o ouvido [...] nas categorias técnicas se revela, essencialmente, a interconexão de sentido" (ADORNO, 2011, p. 61). Vale lembrar a distinção, na língua portuguesa entre ouvir e escutar. Ouvir é aquilo que o ouvido capta, ao passo que escutar significa ouvir com atenção. No caso dos agentes do campo, a escuta a que me refiro e que denominei de escuta ativa musical ${ }^{1}$, se aproxima do sentido de ouvir com atenção, mas vai além, pois envolve uma escuta diferenciada, que pressupõe uma ação e um trabalho mental, um ouvir amparado por teoria e técnica. Acredito que uma situação de campo ajude a entendermos melhor a escuta ativa praticada na Escola de Música. Durante uma aula de regência, o aluno declarou estar inseguro, antes de iniciar a demonstração da regência de Pavane, de Fauré, que foi passada como lição de casa. O maestro diz para Rodrigo, antes de ele começar: "Eu quero que você tente ouvir o máximo da orquestra" (Notas de campo. Setembro de 2014). 
Por ter sido enunciado durante uma aula de regência, nenhum instrumentista executava nada, já que participavam da aula apenas Rodrigo, Samuel e eu. Em uma partitura específica para o regente, há diversas pautas musicais, cada uma relativa a um instrumento, como flauta, violinos, baixos, oboé, etc. A obra era passada para estudo e cabia ao aluno regê-la para que o professor pudesse avaliá-lo e sugerir melhoras na regência, além de naturalização dos movimentos, automatização das marcações de tempo com a batuta e imaginar em que trechos ele deveria ajudar mais os instrumentistas. É, portanto, um trabalho que envolve análise musical do maestro e antecipação de problemas na interpretação/execução do músico, buscando soluções no gestual para estabelecer uma comunicação com os músicos que permita a manutenção de uma posição ou re(alinhamento), de acordo com os microenquadres que compõem o enquadre maior de ensaio de orquestra ou apresentação. Os músicos estão sempre "presentes" nesse trabalho de imaginação musical do maestro, mas de forma virtualizada. O maestro chegava mesmo a apontar para mim, dizendo que eu seria instrumento tal (como a viola, por exemplo). Indaguei ao aluno se, assim, ele conseguia se situar melhor em como dar as entradas para os diferentes instrumentistas. Ele disse que ficava bem mais fácil, já que a posição dos instrumentos na orquestra é fixa. Ao trabalhar com Turner $(1985$; 1988) e mesmo Goffman $(1995 ; 2002)$, conhecidos pela perspectiva ritual de dramatúrgica, coloco-me mais em sintonia com os paradigmas discursivos do diálogo, polifonia e negociação entre o etnógrafo e os sujeitos da pesquisa que propriamente o paradigma da "autoridade etnográfica”. Obviamente que interpreto o tempo todo, já que isso é uma prerrogativa de qualquer ator social nos processos interacionais do cotidiano, mas busco trazer para o centro da cena a intersubjetividade de toda fala, juntamente como seu contexto performativo imediato.

Samuel e Rodrigo consultavam a partitura de Pavane e conseguiam "ouvir a orquestra", por meio de uma dimensão meramente mental, imaginativa. Maestro, aluno e vários músicos me explicaram que, ao lerem a partitura, podiam ouvir a música em suas cabeças. Samuel chegou a confessar que tinha parado de estudar até tarde da noite, pois "a música ficava na cabeça" e ele não conseguia dormir (Notas de campo. Novembro de 2013). Essa escuta imaginativa é ainda mais presente no trabalho do maestro que no do músico, já que aquele não dispõe de instrumentistas que produzam os sons durante as aulas de regência. Durante uma aula de regência, Samuel explicita claramente a impossibilidade do aluno em testar.

Rodrigo: eu tinha ensaiado de uma outra forma. Posso fazer do meu jeito?

Professor: só dá para saber testando com a orquestra, pois tem que ver se os músicos entenderam. Infelizmente você não tem uma orquestra para praticar (Notas de campo. Fevereiro de 2014). 
É notório, portanto, como esse self profissional, no espaço acadêmico, se constitui de uma maneira quase "especular", apesar da valorização da prática como componente de suma importância no meio musical. A imaginação sonora, necessária a preparação do regente em formação e também utilizada pelo músico, no caso do maestro é incrivelmente complexa, pois ele precisa "escutar" todos os instrumentos, vários simultaneamente, tudo isso no pulso da música, levando em consideração entradas e dinâmicas. Nessa mesma aula em que trabalhavam a partir de Pavane, o aluno se queixou da dificuldade em reger uma obra, alegando que "sai som de tudo quanto é lugar", ao errar a regência de uma passagem. O fato de "sair som de tudo o que é lugar" mais uma vez demonstra um trabalho de imaginação sonora que pauta o gestual executado durante a aula, pois o som estava presente na imaginação do professor e do aluno, que, ao consultarem a partitura, conseguiam "escutar os sons" em suas mentes. Outro exemplo de trabalho imaginativo sonoro é a recomendação de Samuel para Rodrigo, ao nos dirigirmos para a saída da universidade, após a aula de regência, de "colocar o metrônomo dentro dele”, para não perder o pulso, já que Rodrigo tinha executado exercícios rítmicos do livro de (RINALDI; DE LUCA; NERY; VAZZOLER, 2008) e tinha apresentado certa dificuldade.

Por conta desse trabalho de imaginação musical, eu ficava muitas vezes aflita e até entediada durante as aulas de regência, pois apesar de perceber que com o avançar do tempo eu entendia algumas questões técnicas, assistir aos exercícios em que o aluno "regia" as notações da partitura me causava a sensação de estar assistindo um filme mudo. Era um alívio quando o maestro decidia cantarolar junto para ajudar o aluno, o que me dava alguma concretude e me ajudava a entender um pouco do gestual e das expressões faciais dos atores. A impressão era de que o filme mudo ganhava legenda.

Os alunos de regência orquestral somente conduzem um concerto no último período, que deve ter, de acordo com a grade de regência, no mínimo 30 minutos de duração, sendo incumbência do formando providenciar também as notas do programa ${ }^{2}$. O estudante de regência pode ensaiar com os alunos da disciplina de Prática de Orquestra, com supervisão do maestro responsável pela cadeira, somente para esse concerto. Ou seja, apesar de terem aulas práticas, como Regência I, II e III, observadas por mim, o contato com uma orquestra só acontece no final da formação ${ }^{3}$, fato que explicava o nome do principal livro da ementa de regência, intitulado $O$ regente sem orquestra, organizado pelo maestro Roberto Tibiriçá. É um livro que enfatiza muito a questão rítmica e traz uma série de partituras e propostas de exercícios, fornecendo bases para o estudante de regência treinar, pois, "o regente é também um instrumentista e seu instrumento é a orquestra ou coro, porém não lhe é dado, com a frequência desejada, seu instrumento para o estudo e aprimoramento da técnica" (RINALDI et al., 2008, p. 13). Nesse sentido, a 
preparação do regente, assim como dos músicos, é feita individualmente, mas o estudo do regente se difere no sentido de que o maestro não executa um instrumento de fato, pois sua função é a de coordenar todos os instrumentistas.

Cabe ao regente idealizar a música como deseja ouvir e planejar estratégias para que o resultado almejado seja alcançado. Para tanto, deve prever a reação dos músicos aos comandos na partitura e ao gestual empregado, já que durante o ensaio não há muito tempo disponível para erros e testes. O professor de regência atuava como um especialista em treinamento, conforme aponta Goffman:

[...] os indivíduos que desempenham este papel têm a complicada tarefa de ensinar ao ator como construir a impressão desejada, enquanto ao mesmo tempo assumem a função de futura plateia e ilustram, por meio de punições, as consequências das impropriedades. Os pais e professores escolares são talvez o principal exemplo [...] (GOFFMAN, 1985, p. 148).

A dimensão do especialista em treinamento é também visível quando o maestro propunha que determinado gestual não funcionaria para os músicos, gerando incerteza, ou discorria sobre a necessidade do gestual do regente ser econômico, ressaltando que muitos maestros fazem "firula" para a plateia somente, sendo possível adotar uma regência clara e concisa, o que evitaria a confusão na comunicação com os músicos. Essa relação estreita entre gestual (imagem) e som (sonoridades organizadas) nos lembram novamente a ideia de uma paisagem sonora (MAFESSOLI, 1996) ou som como imagem simbólica (DURAND, 2001).

Durante as aulas, além de compreender a partitura e conseguir executá-la por meio de uma linguagem gestual, ocasionalmente eram pensadas soluções e adaptações para evitar confusão com a orquestra, quando, por exemplo, o professor pede para o aluno mudar o jeito que estava batendo a batuta porque se fossem os músicos da orquestra da universidade, eles teriam dificuldade e não entenderiam. A clareza do gestual, portanto, é tida como uma das principais obrigações do maestro e integra as ambiências sonoras da escola de música, já que os gestos envolvem também potencialidades das imagens sonoras e emoções, expressando "a vida coletiva, os simbolismos e as práticas dos grupos que os habitam" (VEDANA, 2010, p. 12).

A clareza dos gestos tem relação com o entendimento do som da obra, que decorre por meio de estudo detalhado da partitura. A escolha de um repertório de gestos se dá pela "natureza do som que também determina a técnica adotada" (Samuel. Novembro de 2014). A solução para os problemas na definição da regência ocorre, primeiro, por meio do ouvido, como na fala de Samuel a Rodrigo, que recomendou ao aluno cantar, fosse mentalmente ou emitindo som. A ideia era amenizar a dificuldade em reger um trecho da partitura. "Está com um problema para reger? Esquece a batuta e canta. Precisa trabalhar mentalmente sempre" (Notas de campo. Novembro de 2014). 
O repertório gestual, portanto, seria concebido a partir do estudo da partitura, de acordo com o que "a música pede", conforme explicou o maestro. Ou seja, é preciso primeiro entender com o ouvido para depois pensar em como irá estabelecer o contato com os músicos no nível visual/gestual.

A necessidade de uma escuta ativa e apurada era tão forte no campo que mesmo eu, atuando como pesquisadora, precisei estar mais atenta em minha escuta, apesar de compreender que nunca teria a escuta ativa musical do perito em música. Buscava, no entanto, ser ao menos uma ouvinte atenta, alguém capaz de tecer juízos minimamente fundamentados. Esse ligeiro aumento de minha capacidade auditiva ficou perceptível um dia em que minha mãe assistiu ao ensaio da orquestra de alunos comigo e com o aluno de regência. Num determinado momento, após o corte do maestro, percebi que sobrou uma nota de um instrumento de sopro. Perguntei ao aluno qual era o instrumento e ele respondeu de pronto: oboé. Minha mãe disse que não notou nada de errado, nem mesmo a nota, quanto mais a família de instrumentos a qual pertenceria o músico responsável pela "nota extra". No final do ensaio, ela se queixou de dor de cabeça, dizendo que quando eles tocaram foi bonito, mas o barulho que faziam antes do ensaio era incômodo". Vale ressaltar que antes do maestro chegar e iniciar o ensaio, é usual os músicos afinarem seus instrumentos e, cada qual, executar trechos aleatórios. Apesar um uma etiqueta tácita, que sugere uma execução mais baixa, muitos se exaltam em um momento ou outro, o que demonstra a ambivalência razão/emoção no fazer música. Ademais, mesmo tocando em baixo volume, quarenta instrumentos tocando obras e trechos distintos causam um verdadeiro "caos sonoro", incômodo para os que não estão acostumados. Isso gerava um incômodo para mim especialmente no início do campo, tendo melhorado cerca de três meses após a primeira observação. Ocorre que é possível pensar em termos de uma antropologia do ruído, pois se "você tem um barulho percutido qualquer e ele começa se repetir e a mostrar certa periodicidade, abre-se um horizonte de expectativa e a virtualidade de uma ordem subjacente ao pulso sonoro em suas regularidades e irregularidades" (WISNIK, 2011, p. 33).

Para os agentes do campo, a necessidade da escuta ativa musical para frequentar o local era tão intensa que Rodrigo e Samuel tinham dificuldade em entender o quão leiga eu era, tentando, recorrentemente, discutir comigo questões mais técnicas. Isso ocorreu principalmente nos dois primeiros meses do trabalho de campo. Com o avançar no campo, eles foram percebendo que eu não tinha condições de fazer as mesmas análises musicais que eles e diminuíram as investidas, mas, ocasionalmente, perguntavam minha opinião em relação à qualidade do som da orquestra em uma determinada peça, ou mesmo sobre a postura de Rodrigo e seu trabalho corpóreo-gestual. Eu geralmente respondia de maneira menos específica, falando que achei bonito o som, apontando 
a execução de uma peça que achei melhor, mas nesse ponto, conseguia perceber a objetividade da escuta ativa musical, pois Rodrigo alegava, por exemplo, que o "som do órgão estava baixo", que "as violas estavam correndo", "que os cantores não respeitavam o tempo" ou "que tem sempre um maldito que não respeita o corte seco e executa uma nota longa".

Tais falas remetem a um universo em que o som é referência, configurando-se a escuta, em algo muito ativo, diferentemente de uma noção do senso comum em que o ouvir aparece muitas vezes como gesto que denota passividade. Ouvir, para esses profissionais, significa um tipo de ação que aciona uma vasta bagagem de teoria e técnica, articulado também com as dimensões visuais e táteis. Toda essa bagagem é evocada para o momento do exercício da escuta, tanto a escuta de colegas tocando, que nunca é uma escuta distraída, mas atenta e ativa, e para o ato de tocar, seja sozinho ou em conjunto, em que escutar e ver, compreender a paisagem sonora em questão são fundamentais para a boa execução e reorienta a ação constantemente.

Mas qual o espaço para a emoção face a escuta ativa musical, que pressupõe uma racionalidade amparada pela técnica? Vale lembrar que a emoção também era tematizada por Samuel e Rodrigo, mas o professor explicou que a ênfase seria dominar a técnica, os andamentos e entradas, para depois eles pensarem em questões de ordem emotiva. Como esse foi o momento da formação do regente que acompanhei a ênfase nessas situações técnicas foi mais intensa. No entanto, em algumas ocasiões o professor tecia algum comentário que sublinhava a emoção na música, dizendo, por exemplo, para Rodrigo desenhar mais o movimento e marcar menos, ao reger uma partitura cuja música, segundo Samuel, exigia mais "paixão" - novamente a questão do som como imagem simbólica aparece. Samuel, em um dia após uma apresentação da orquestra de alunos, conversava com um compositor cuja obra foi tocada pelo grupo. Samuel comentou com o colega que um renomado maestro brasileiro estaria num outro grau de relação com a música, e que, por isso, às vezes deixava as coisas um pouco soltas e os músicos ficavam na mão. Disse que os músicos da OSESP sempre reclamavam disso (Notas de campo. Maio de 2014).

De qualquer forma, tanto na dimensão mais racional quando na mais emotiva da Música, são necessárias o exercício da escuta ativa, condição fulcral para participar do universo orquestral ${ }^{4}$, pois os agentes do campo são questionados de maneira recorrente sobre uma obra ou ária, além de precisar, obviamente, da capacidade auditiva para tocar. O nível de tal escuta implica vasto conhecimento musical, teórico e técnico, que se tornam visíveis na performatização empreendida pelos demais agentes, seja no plano verbal, ao fazer alguma consideração sobre uma música, ou durante a execução de uma obra - aspecto que eles consideram mais importante. A escuta ativa é condição para os sujeitos serem capazes de decodificar a linguagem musical, que subentende uma 
gramática, composta por signos, como as notações musicais, que auxiliam na interpretação e na leitura da obra e na performance musical.

Integra essa linguagem musical também a visão, que se torna importante no ensaio e em um espetáculo sonoro, pois há uma conjugação do ouvir e ver na fruição musical. O músico e o regente para fazerem "soar bonito", como os agentes do campo costumam dizer, e que mais uma vez nos remetem à questão de uma "imagem sonora" (VEDANA, 2010), precisam de uma destreza motora ímpar, o que ajuda a compor a aura do espetáculo. Além disso, temos em jogo toda uma dimensão expressiva que transparece para a plateia e surge não só a partir do ouvir e tocar, mas também de expressões faciais, movimentos corporais e o jeito de olhar. Esse conjunto de atributos, nos termos de Goffman, a expressão dada (information given), envolvendo símbolos cuja intenção é deliberadamente comunicar algo, e a expressão emitida (information given off), por meio da qual algo é comunicado involuntariamente, podem ajudar a entender por que ver um espetáculo sonoro o torna tão mais interessante do que apenas ouvi-lo.

Uma determinada expressão facial tanto pode ser "expressão dada", quando o músico opta por uma feição que julgue combinar com o caráter da música, como pode ser comunicada involuntariamente, com o instrumentista se deixando envolver pela música e sem perceber que está adotando uma determinada expressão facial. Ou seja, reconheço a grande importância do "ouvir" para os atores, mas o ver também é relevante, especialmente em apresentações, pois, no ensaio, não goza do mesmo grau de relevância, já que não há plateia, tendo em vista que a interação se desenrola apenas com os membros da equipe e orquestra de alunos, numa situação típica de bastidores (GOFFMAN, 1985). Mas mesmo no ensaio a visão se faz presente, pois é necessário olhar de vez em quando para o maestro, consultar a partitura. Além disso, o músico não toca constantemente, atacando e atuando apenas em trechos específicos, o que o obriga a ficar acompanhando a partitura. A destreza do tocar não é checada apenas por meio da audição, mas também, pensando num instrumento de cordas, por exemplo, em como o instrumentista se posiciona, sua técnica com o arco, os golpes de arco que executa, e sua expressividade e colorido, que associa som à performatização (tocar, jeito de tocar, héxis corporal adotada, expressão facial e trejeitos). Vimos, portanto, que ouvido e olho são ferramentas de comunicação importante, tanto do regente e dos músicos para com a plateia, durante a execução de um espetáculo, quanto entre regente e músicos no espetáculo e nos ensaios. Isso fica nítido na fala do professor, quando discute o papel do maestro frente a orquestra durante uma aula de regência, trazendo à tona a questão do olhar: "O papel do maestro é o de unificar. Você dá seu olhar. Unifica o grupo através do olhar. Eles acabam saindo um pouco da partitura. O pessoal concentra mais. 'Tipo: o maestro está olhando para a gente”' (Samuel. Notas de campo, maio de 2014). 
Relevante lembrar que o olhar subentende uma questão de vigilância, em uma relação de autoridade, amparada por uma dupla hierarquia - no caso do campo, de professor e maestro, e alunos e instrumentistas. O próprio professor de regência parece reconhecer essa nuance disciplinadora do olhar que "vigia e pune", para nos valermos do célebre título de Foucault, pois explica para o aluno que "os olhos são uma grande ferramenta de controle da orquestra" e pede, em seguida, para Rodrigo, antes de retomar a execução da partitura, "dar aquele olhar autoritário antes de começar a reger” (Notas de campo, 04 de setembro de 2014). O posicionamento diante da orquestra também é praxe, pois permite não só um monitoramento pelo olhar, mas também é considerado, como vimos a partir do campo, essencial na comunicação com os músicos, inclusive para sinalizar as entradas por meio dos olhos. A ideia é que enquanto aponta a batuta para uns, dirige o olhar para outros. Sendo assim, o regente conseguiria dar as entradas para dois instrumentistas que, porventura, entrem juntos, cabendo a ele priorizar para quais ele sinalizará.

Mas os olhos vão além, servindo de encorajamento para um músico num trecho difícil, para, associado ao semblante, transmitir o espírito da música, deixar os músicos alertas para uma parte específica que possa ter sido problemática no ensaio, entre outras funções. Com relação aos gestos, apesar de determinados movimentos variarem de acordo com o regente, o uso dos braços e da batuta é algo universal, e, obviamente, também praticado por professor e aluno no campo, apesar de existirem alguns poucos regentes que prefiram usar apenas as mãos. Devemos lembrar que no contexto do ensaio e mesmo da apresentação da orquestra, uma dimensão não verbal da comunicação se faz presente, através dos gestos e do olhar, o que possibilita o monitoramento mútuo desses atores.

Samuel explicou, em uma aula de regência, como Rodrigo deveria abrir um ensaio. Nessa ocasião, acredito que essa questão da dimensão não verbal da comunicação maestro/músico tenha ficado mais nítida. $\mathrm{O}$ professor brincou dizendo que uma fala comum entre os músicos é a de que "sabemos quem é o regente só pela maneira como ele sobe ao pódio". Completou explicando que não era bem assim, que existiam certos "macetes" para o maestro construir uma imagem respeitosa. Ponderou que além de demonstrar certa autoconfiança no andar e no falar, no domínio da partitura, que ajudaria nessa imagem confiante, "o regente deve subir ao pódio, dispor a partitura na estante, olhar para os segundos, para as violas, 'ciellos' e contrabaixos e se certificar 'tá todo mundo me olhando', e começa e deixa fluir". Concluiu afirmando que o maestro "não marca apenas compassos. Interage também com a orquestra" (Notas de campo. Dezembro de 2014).

A linguagem musical, no âmbito orquestral, recorre mais fortemente ao ouvido e aos olhos, utilizados para monitoramento dos atores envol- 
vidos com a orquestra. Boa parte desse monitoramento visual do músico para com o regente ocorre por meio da batuta, que deve estar sempre visível, pois "é um prolongamento do corpo", como explicou o professor. Tal fala, muito similar a ideia dos "meios de comunicação extensões do homem”, (MCLUHAN, 1996), realmente se aplica a orquestra, pois a batuta funciona como um prolongamento do braço e das mãos do regente.

O objetivo ao usar a batuta, conforme explicou Samuel em uma aula de regência, é fazer a orquestra caminhar no mesmo tempo, "desde o início você impõe a seguinte questão: eu estou longe de você, mas estou no comando" (Notas de campo. Dezembro de 2014). Ou seja, a batuta ajuda na comunicação maestro-músico, ao prolongar a extensão do braço e mãos do maestro e, consequentemente, auxilia a manter os músicos sob controle.

Outro exemplo que demonstra a relação entre o olhar e o trabalho de monitoramento maestro/músico pode ser ilustrado a partir de uma situação de campo. Certa vez, durante uma aula de regência, o maestro criticou a maneira como o aluno projetava a batuta ao estender o braço, com a palma da mão virada para cima, em formato de concha e o braço arqueado, alegando que parecia que ele ia "se apresentar para alguém".

Samuel disse não achar eficiente, explicando que poderia confundir os músicos. O professor alegou ser melhor apontar em direção ao músico, pois "o maestro bom é como um polvo, vai mostrando os tentáculos para a orquestra”. Outra metáfora que ele usou para explicar o movimento que ele esperava do aluno foi pedir para ele fingir que estava tirando uma ponta de cigarro ou ainda pintando um quadro. Mas outros elementos não sinalizados na fala do professor também estavam em jogo, como a expressão facial de Samuel, mais confiante que a de Rodrigo, sendo mais enfática e destacando os músicos que deveriam entrar, pois ele imaginava o posicionamento dos instrumentistas, cuja formação é fixa, com cada família de instrumento divididas, além de existir uma divisão por níveis (primeiros e segundos instrumentistas). O movimento de Rodrigo parecia convidar os músicos, sem direcionar muito bem quem seriam os convidados

Outro exemplo que denota a importância do olhar ocorreu na aula de Prática Orquestral, quando Samuel solicita a um instrumentista que olhe para ele, após o jovem errar o andamento da música: "Olha para mim, Vicente (pseudônimo). Preciso de contato visual com você nessa parte". (Samuel. Notas de campo, novembro de 2013).

O instrumentista, calouro na universidade, ainda estava muito preso em sua partitura, segundo Rodrigo, que assistiu comigo ao ensaio. Isso dificultava que o instrumentista acertasse o tempo, destoando dos demais colegas. Após o pedido do professor, o instrumentista insistiu em tocar sem olhar para o mestre, possivelmente por insegurança em se perder na partitura. Rodrigo comenta que ele ainda estava atrasado no tempo. O maestro pede para o aluno tocar novamente e, nessa terceira 
vez, ele olha para o regente, conseguindo executar a contento. Rodrigo comenta comigo: "Ah! Agora sim, né?!"

Em um dia de ensaio, Samuel pede, em tom de brincadeira, para o coro "exagerar em um trecho, tocar de maneira mais intensa, fazer 3D, porque agora é moda. Vocês devem deixar visível para a plateia”. Essa brincadeira, que arrancou alguns risos de instrumentistas e cantores, inclusive o meu, é uma analogia curiosa se pensarmos que uma realidade em três dimensões envolve mais a visão que qualquer outro sentido. Mas o que o maestro queria era mais força sonora, o que vai ao encontro do som como imagem. No entanto, essa força se faz visível para a plateia não só por meio do ouvido, mas pela própria postura corporal, expressões faciais e gestos, compondo uma paisagem sonora.

\section{CONCLUSÃO}

A expressão "o olho escuta", cunhada pelo poeta francês Paul Claudel $^{5}$, elucida o caráter interdependente que as faculdades do ouvir e ver desempenham no trabalho interacional do músico e do maestro de orquestra. Lago (2008) utiliza as construções "perceber o som" e "consciência musical" também pensando nessa inter-relação ouvir/ver, afirmando que um músico profissional "apreende a música de um modo comparável ao que nos chega quando estamos num dado ambiente e podemos visualizar, simultaneamente, toda a pluralidade de realidades imediatas que nos cercam" (LAGO, 2008, p. 187), englobando nesse jogo não apenas as mensagens sensoriais sonoras, mas também toda a ordem de mensagens não verbais provenientes dos gestos, do semblante do regente e do olhar.

Portanto, as faculdades do ouvir e do ver, em etnografias que investiguem mundos musicais, não podem ser dissociadas, inclusive dos outros sentidos, pois integram as pistas de contextualização a partir das quais podemos agir no jogo interacional. $\mathrm{O}$ que busquei ressaltar foi a importância de audição e visão para os nativos do campo Escola de Música e o fato de etnografias sonoras estarem lidando com imagens sonoras. Apesar da visão ser comumente a capacidade mais valorizada para compreendermos a realidade a nossa volta, esta dialoga intensamente com a audição, e com os demais sentidos em menor escala, na performance dos músicos e maestro.

As pesquisas que enfoquem universos musicais estão lidando com um objeto que é invisível, impalpável, subjetivo, e que se constitui a partir de uma relação som/silêncio, sendo a música dinamogênica, com capacidade de nos invadir, maravilhar e aterrorizar - não atoa é tida por inúmeras culturas como algo mágico, fetichizado, um talismã e caminho de uma comunicação com deidades.

O nativo, no campo investigado, no qual a música é atividade profissional dos sujeitos, é habitado e experenciado a partir de uma escuta 
ativa. Tal escuta, por sua vez, aciona constantemente a visão, em especial no monitoramento maestro/músico. Ouvir, para esses profissionais, significa um tipo de ação que mobiliza uma vasta bagagem teórica e técnica, diferentemente do significado normalmente atribuído no senso comum, que associa ouvir à passividade.

No campo, a escuta nunca é distraída e passiva, mas ativa, sendo exercida quando o músico toca sozinho, em conjunto ou mesmo quando lê a partitura, pois instrumentistas e regente possuem o que chamei de imaginação musical, só possível a partir do domínio da escuta ativa musical. Ao lerem uma partitura, os nativos alegam que efetivamente a "escutam em suas cabeças", incluindo Samuel e Rodrigo, que acionam intensamente essa dimensão imaginativa da escuta nas aulas de regência, nas quais nenhum músico estava presente e, portanto, nenhum som era efetivamente emitido. Ocasionalmente, cantarolavam uma melodia que regiam, mas durante boa parte da aula Samuel e Rodrigo ficavam mudos, com este demonstrando o estudo que fizera da regência e aquele consultando, esporadicamente, a partitura e checando o desempenho de Rodrigo.

A escuta dos integrantes do mundo orquestral, portanto, é ativa e técnica, envolvendo uma dimensão imaginativa, que só pode ocorrer em função do preparo técnico dos nativos. Ao longo de seu processo de formação, Rodrigo precisava se valer da escuta imaginativa, pois a orquestra e os instrumentistas eram projetados, sendo o foco de seu trabalho não só se apossar dos gestos, automatizando os movimentos o máximo possível, inscrevendo-os em sua memória corpórea, mas também prever como os músicos interpretariam seu gestual, pensar em um repertório de gestos que não causasse confusão, e buscar soluções para trechos possivelmente problemáticos. O discurso verbal, tanto em situações de ensaio como de apresentação, não é valorizado pelos nativos que, inclusive, afirmam que maestro que fala muito "não se fez claro", ou seja, tem dificuldade de se fazer entender por meio da linguagem musical.

O ouvir/tocar, para o músico, é uma atividade, uma performance. Aquele que pratica a performance se concentra em sua ação, e o público se concentra em assistir. No caso da performance do músico teríamos o instrumentista fazendo as duas coisas, se concentrando em ouvir, apurando a escuta, e se concentrando nos gestos do maestro ao mesmo tempo que se fixa em sua ação. A ação e audição, no maestro, estão ligadas a uma forma de exame que nós costumamos associar à visão; ele escuta com atenção da mesma forma que dizemos para alguém olhar com atenção. 


\section{NOTAS}

1. A escuta psicanalítica demonstra que o ato de escutar, em algumas profissões, envolve pura ação, sendo o mecanismo fundamental para organizar determinadas atividades profissionais. É precisamente o que ocorre na profissão de músico e maestro.

2. Ao fazer as notas do programa o regente deve sinalizar nome da obra, autor e ano da composição. As notas também costumam contextualizar a peça, ao trazer informações sobre a vida do autor, movimento artístico no qual se inseria e características técnicas e artísticas da obra.

3. Infelizmente não tive a oportunidade de observar Rodrigo interagindo com os alunos nos ensaios, pois Rodrigo trancara o curso poucos meses após eu deixar o campo.

4. Para fazer parte desse universo orquestral, é necessário conhecimentos e habilidades a priori, diferentemente de outros cursos da graduação. Todos os alunos de Música e os aspirantes ao curso de regência passam por um teste de Habilidades Específicas para inferir o nível musical, cuja natureza é eliminatória e classificatória. Os agentes do campo explicavam que a prova mais difícil era justamente a do regente.

5. Paul Claudel foi o nome artístico de Louis Charles Athanaïse Cécile Cerveaux Prosper, um diplomata, dramaturgo e poeta francês, membro da Academia Francesa de Letras, nascido em 1869.

\section{REFERÊNCIAS}

ADORNO, Theodor. Regente e orquestra: aspectos sociopsicológicos. In: ADORNO, T. Introdução à Sociologia da Música. Trad. Fernando Moraes Bastos. São Paulo: Unesp, 2011.

ANGROSINO, Michael. Coleta de dados em campo. In: ANGROSINO, M. Etnografia e observação participante. Trad. José Fonseca. Porto Alegre: Artmed, 2009. (Coleção Pesquisa Qualitativa).

BASTOS, Rafael Menezes. Esboço de uma Teoria da Música: Para Além de uma Antropologia Sem Música e de uma Musicologia Sem Homem. Anuário Antropológico/1993, Rio de Janeiro, p. 9-73, 1995.

BENJAMIN, Walter. A Obra de Arte e a era de sua reprodutibilidade técnica. In: BENJAMIN, W. Walter Benjamin. Magia e técnica, arte e política. São Paulo: Brasiliense, 1993.

CANETTI, Elias. O regente. In: CANETTI, E. Massa e poder. Trad. Sérgio Tellaroli. São Paulo: Cia das Letras, 1995.

DURAND, Gilbert. As Estruturas Antropológicas do Imaginário. São Paulo: Martins

Fontes, 2001.

GAMA, Fabiene. Sobre emoções, imagens e os sentidos: estratégias para experimentar, documentar e expressar dados etnográficos. Revista Brasileira de Sociologia da Emoção, v. 15, n. 45, p. 116-130, 2016. 
GELL, Alfred. The Language of the Forest Landscape and phonological iconism in Umeda In: HIRSCH, Eric; O'HANLON, Michael (Orgs.). The Anthropology of Landscape: Perspectives on Place and Space. Oxford: Clarendon Press, 1995.

GOFFMAN, Erving. Footing. In: RIBEIRO, B. T., GARCEZ, P.M. (Org.). Sociolinguística Interacional. São Paulo: Loyola, 2002.

GOFFMAN, Erving. A representação do eu na vida cotidiana. Trad. Maria Célia Santos Raposo. Petrópolis: Vozes, 1995.

INGOLD, Tim. Pare, Olhe, Escute! Visão, Audição e Movimento Humano, Ponto Urbe [On-line], n. 3, p. 1-53, 2008. Disponível em: < https:// journals.openedition.org/pontourbe/1925>. Acesso em: 25 nov. 2020.

LAGO, Sylvio. Arte da regência: história, técnica e maestros. São Paulo: Algol Editora, 2008.

LE BRETON, David. Antropologia dos sentidos. Petrópolis: Vozes, 2016. MAFFESOLI, Michel. No Fundo das Aparências. Petrópolis: Vozes, 1996.

MCLUHAN, Marshall. Os Meios de Comunicação como extensões do homem: understanding media. São Paulo: Cultrix, 1996.

MERLEAU-PONTY, Maurice. Le Visible et l'Invisible: suive de notes de Travail. Texte établi par Claude Lefort. Paris: Gallimard, 1964.

OLIVEIRA, Roberto Cardoso. O trabalho do antropólogo: olhar, ouvir, escrever. In: OLIVEIRA, R.C. O trabalho do antropólogo. São Paulo: Unesp, 2000.

PINTO, Tiago de Oliveira. Som e Música: questões de uma antropologia sonora. Revista de Antropologia, São Paulo, USP, v. 44, n. 1, p. 221-286, 2001. RIBEIRO, Fabio Henrique. Estudos etnomusicólogos brasileiros e a cultura popular contemporânea em performance. In: PRASS, Luciana; VICENZO, Edilberto Fonseca (Org.). Anais [do] VIII Encontro Nacional da Associação Brasileira de Etnomusicologia - VIII ENABET, Rio de Janeiro, 2017, p. 331-339.

RINALDI, Arthur; DE LUCA, Beatriz; NERY, Daniel; VAZZOLER, Luciano. O regente sem orquestra: exercícios básicos, intermediários e avançados para a formação do regente. Roberto Tibiriçá (Org.). São Paulo: Editora Algol, 2008.

ROCHA, Ana Luiza Carvalho da; VEDANA, Viviane. A representação imaginal, os dados sensíveis e os jogos da memória: os desafios do campo de uma etnografia sonora. VII Congresso de Antropologia do MERCOSUL (VII-RAM). Anais... Porto Alegre, 2007.

SEEGER, Anthony. "What can we Learn When They Sing? Vocal Genres of the Suyá Indians of Central Brazil”, Ethnomusicology, v. 23, p. 373394, 1979.

SILVA. Joao. Construindo a profissão musical: uma etnografia entre estudantes universitários de música. 2005. 288 f. Tese (Doutorado em Música) - Departamento de Música da UNIRIO, Rio de Janeiro, 2005. 
SILVA, Helio. A situação etnográfica: andar e ver. Horizontes Antropológicos, Porto Alegre, v. 15, n. 32, p. 171-188, 2009.

STOLLER, Paul. The Taste of Ethnographic Things: The senses in anthropology. Philadelphia: University of Pennsylvania Press, 1989.

TRAVASSOS, Elizabeth. Esboço de balanço da etnomusicologia no Brasil. Opus: Revista da Associação Nacional de pesquisa e Pós-Graduação em Música - ANPPOM, Campinas, ano 9, n. 9, p. 73-86, 2003.

TURNER, Victor. "Foreword”. In: SCHECHNER, Richard. Between theater and anthropology. Philadelphia: University of Philadelphia Press, p. xi-xii, 1985.

TURNER, Victor W. The Anthropology of Performance. New York: PAJ Publications, 1988.

VEDANA, Viviane. Territórios Sonoros e ambiências: etnografia sonora e antropologia urbana. Iluminuras, Porto Alegre, v. 11, n. 25, p. 1-15, 2010.

VELHO, Gilberto. Observando o familiar. In: NUNES, Edson (Org.). A Aventura Sociológica. Rio de Janeiro: Zahar, 1978.

WISNIK, José Miguel. Antropologia do ruído. In: WISNIK, J.M. Som e sentido. São Paulo: Cia das Letras, 2011. 